\title{
THE EFFECT OF DISCIPLINE, ORGANIZATIONAL COMMITMENT AND WORK ENVIRONMENT TO GAIN TEACHER PERFORMANCE IN PAUD
}

\author{
Andi Sulistiadi ${ }^{1}$, Otto Berman Sihite ${ }^{2}$, Virza Utama Alamsyah ${ }^{3}$ \\ Universitas Pelita Harapan \\ E-mail: sulistiadiandi@gmail.com
}

\begin{abstract}
This writing aims to prove several HR variables that affect the performance of teachers in this digital learning era. In this era of digital learning, it is believed that the role of the teacher as a channel for children's educators is even replaced by the digital device. Based on this phenomenon, teacher performance is assumed to decrease. This research was conducted at Pelita Harapan BangsaTegal. The study population was 57 teachers and data collection techniques were carried out by distributing questionnaires and the data were analyzed using the Smart PLS research tool.3.0. The results of the analysis show that the HR variable consisting of Work discipline, Organizational Commitment and the Work Environment positively influences teacher performance. HR strategies have positive effects such as: disciplining all levels, expressed organizational commitment and fulfillment, and work costs that are designed as comfortable as possible for teachers can improve.
\end{abstract}

Keywords:Work discipline, Organizational Commitment, Work Environment, Teacher Performance.

\section{INTRODUCTION}

Teachers are the spearhead of an education system. As an educational practitioner who certainly has a very important role for the development of their students which in turn will affect the quality of the school. Thus in this study, what we will study is teacher performance which is sometimes good and then in the next few months performance is assessed to decline. As described above the teacher is one of the human resources who are sensible, feeling, willing, capable, have skills, given knowledge, have encouragement, have power, and are able to create work. The only source that has aspects of taste, intention, and ratio. The overall potential of human resources is assumed to be able to influence the organization's efforts in achieving its objectives. Even though technology science is advancing and developing rapidly, the development of information, the availability of capital and the availability of materials, but in the absence of human resources, it will be difficult for organizations to achieve their goals (Faustino Cardoso Gomes 2002: 2). Seeing the development of the digital era which is quite influential in the world of Education 
including for educators, of course, provides a phenomenon for teacher performance. Where before the digital era, the teacher's role was the only channel in the process of conveying knowledge and even spiritual and character accompaniment to their students who are now channeled by digital media which is the result of technological development. This resulted in the teacher's behavior in carrying out his assignment to be considered to decrease, even with the digital role as a substitute for the teacher's role, teacher's performance was often assessed to decrease. But surely this assumption cannot be trusted as a truth, an analysis must be made stating that teacher performance is actually not disrupted in today's digital era. Therefore, the authors chose to see from the perspective of human resource management to determine teacher performance from discipline, foundation commitment and the school environment.

The place of this research was held at Pelita Harapan Tegal School which is a private school based on national plus holistic education. In line with the perspective and efforts of the foundation which hopes for an increase in good performance of Pelita Harapan Bangsa teachers.

\section{LITERATURE REVIEW}

Teacher's performance is the result of work that appears both tangible and implicit in the context of completing his responsibilities properly (Mangkunegara, 2005: 9). Performance is seen as the process of completing a responsibility and the results of the work. Performance is a process of how the work takes place to achieve work results. But the results of the work itself also show performance.

Work discipline is assessed by several indicators that affect teacher performance. Discipline is an indication that a teacher can complete his task well based on his integrity. It is very difficult for schools / foundations or companies to achieve good goals without the discipline of their teachers (MalayuHasibuan, 2005: 193). Work discipline according to (MalayuHasibuan, 2005: 194) is a person's awareness and willingness to obey and follow school rules and social norms that apply.

An acceptance that has a strong effect that is able to make teachers to hold fast to their vocation and decide to continue to carry out their duties until the school / foundation goals are met in the long term (KhaerulUmam 2010: 259).

School is a work environment for teachers, in which there are a number of areas that indeed affect comfort and even cause a feeling of being at home or a desire to feel comfortable in their work environment (Supardi 2003: 37). In line with the above understanding of the work environment (Sedarmayanti 2007: 105) which states that in general the work environment is divided into two namely: 1) physical work environment, and 2) nonphysical work environment.

Based on the results of previous studies and supported by the theories that have been put forward below is the framework of the research concept in the diagram below: 



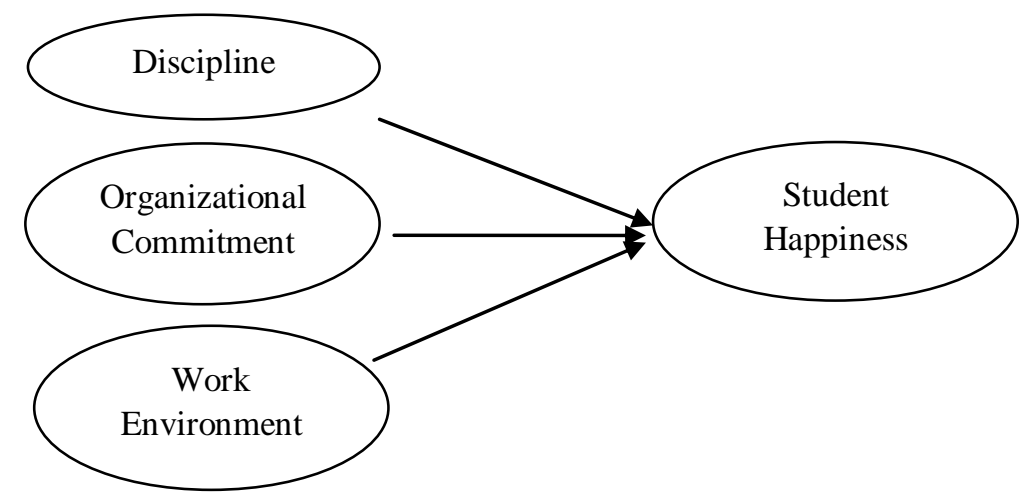

Figure 1. Research Framework

Based on the research hypothesis model that has been made above, the following research hypotheses are formulated: (H1) work discipline has a positive influence on teacher performance, (H2) foundation commitment has a positive influence on teacher performance, (H3) school environment has a significant and positive effect on teacher performance.

The following are the variables that will be used in this study divided into: (1) dependent variables, namely variables whose value is influenced by independent variables. Then as the dependent variable is performance (Y). (2) Independent variable is a variable that can affect changes in the dependent variable and has a positive or negative relationship for the $\mathrm{Y}$ variable. In this study there are 3 independent variables, namely work discipline (X1), organizational commitment (X2), and work environment (X3).

\section{METHOD}

This research was conducted at the Pelegal Harapan Nation School in Tegal (PHB) a PAUD-SD \& SMP tiered school under the auspices of the Tunas Harapan Foundation in the city of Tegal and as the subject of this study was a PHB school teacher. The object of this research is work discipline, foundation commitment, school environment and its impact on teacher performance. The population in this study were 57 PHB school teachers and the determination of the number of samples using the Slovin formula with a degree of confidence of $95 \%$. The sampling technique used is to use simple random sampling based on the drawing of employees' parent numbers randomly taken as many as 57 people.

Analysis on using data analysis methods using Smart PLS software version 3.0. 


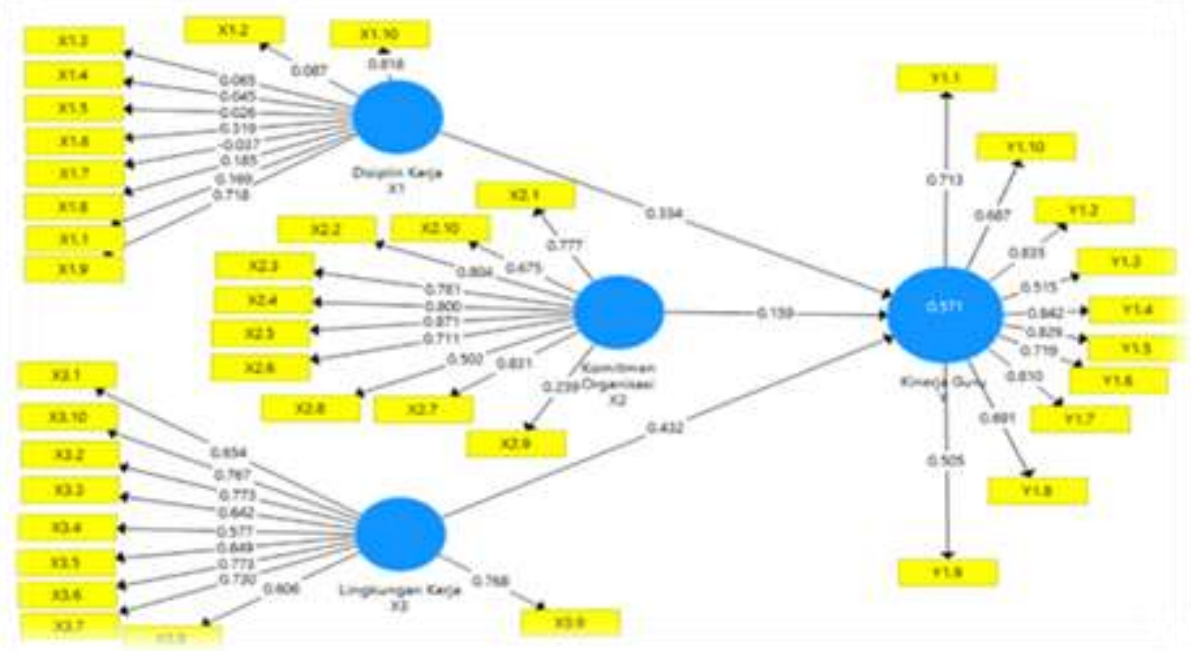

Figure 2. PLS Result

The diagram picture shows the indicators of variable $\mathrm{X}$ have a relationship that is able to affect performance. The accumulation of diagram calculations states that the lowest indicator $\mathrm{X} 1$ is $\mathrm{X} 15(0.026)$ while the highest is $\mathrm{X} 10$ (0.818). While the lowest X2 indicator is X29
(0.239) and the highest is $\mathrm{X} 25$ (0.871). The lowest indicator $\mathrm{X} 3$ is $\mathrm{X} 34(0.577)$ and the highest is $\mathrm{X} 35$ (0.849). While the dependent $Y$ indicator is affected low is Y19 $(0.505)$ and the highest is Y14 (0.842).

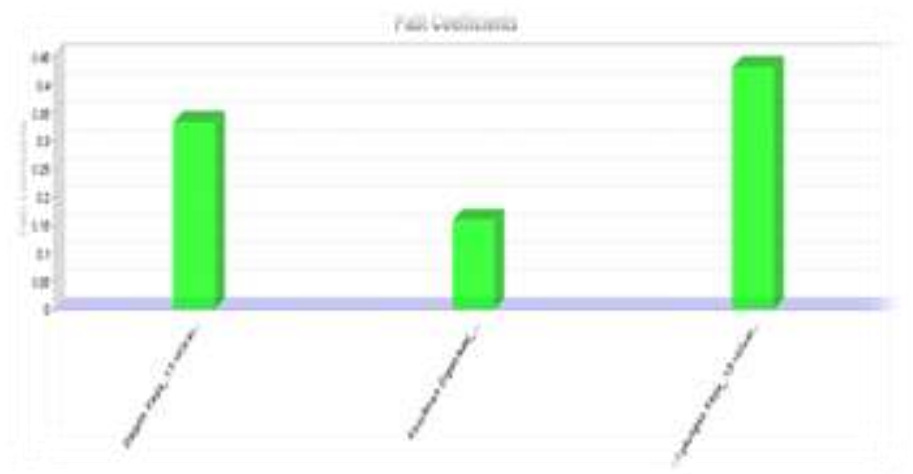

Figure 3. Path Coefficients

Henceforth, based on the diagram of the path bar coefficients diagram, we can analyze that there is a path coefficient path between the three independent variables on the dependent variable. We can see that the three cariables have a positive effect on the $\mathrm{Y}$ variable, while among the three $x$ variables, the highest effect on the $\mathrm{Y}$ variable is the $\mathrm{X} 3$ variable. 
RESULT AND DISCUSSION

Testing using Smart PLS version 3.0 proves that work discipline, foundation commitment, and the school environment simultaneously have a positive influence on the performance of Pelita Harapan Tegal teachers. Test data show that there are consistent observations that are in line with Abdillah's research (2011) which proves that teacher discipline has a positive influence on teacher performance. Hypothesis test results indicate that discipline has a significant effect on teacher performance.

Hypothesis test results indicate that work discipline has a significant positive effect on teacher performance. These results prove that discipline has a positive effect on every change in teacher performance. Calculation results show 33\% influence of discipline on teacher performance. The value is quite large influence. In this case the influential performance is the disciplinary performance on arrival and after work, the teacher's compliance with the use of sophisticated devices to support his teaching needs, the accuracy of the teaching material delivered to students in accordance with the daily and weekly learning plans of the teacher, which of course is adjusted to the textbook.

Discipline is also seen from the accuracy of the teacher completing the evaluation tasks and field reports. The test results show that the commitment of the foundation directly influences positively but not significantly to the performance of the Pelita Harapan Bangsa Tegal teacher. This proves that there is a conformity between the teacher's desire to work as well as possible, the role of the foundation that is able to fulfill every promised and agreed between the foundation and the teacher consistently. Such as the commitment of teachers who are never late will get a walk bonus as a token of appreciation which is realized according to the promised time and place. And also the suitability of the compensation given such as THR given on time with a nominal amount adjusted to the initial commitment.

In addition, the foundation's commitment is able to improve teacher performance which is seen from the enthusiasm and enthusiasm of teachers in completing each of their respective tasks by fulfilling the needs and needs of teaching support, such as the availability of teaching aids, office stationery needs, as well as the availability of supporting devices for teaching and learning activities that have been proposed by the teacher according to operational standards. Hypothesis test results indicate that the school environment has a positive and significant effect on teacher performance. This shows that the school environment is seen 
from the completeness of the facilities and the current support tools needed by the teacher. The teacher feels comfortable with the presence of new items in the class that can help them to complete their daily tasks, such as the availability of an internet connection with good speed, then spread the latest gadgets with the latest technology, Air Conditioner facilities that are able to bring a cool atmosphere in the room, even up to the color of the walls and decoration that makes the teacher feel at home and comfortable being in school. In addition to the physical form of the school environment, it was found that the need for interaction between teachers was also able to influence their performance. Especially with teacher assignments formed in a group work which shows that comfort in teamwork is part of determining the performance of teachers.

The influence of work discipline on teacher performance shows that there is a positive relationship that influences one another. The rules of the school are considered not longwinded and have a fair value to be implemented. Most teachers have stated themselves to obey the discipline of time and also any rules that apply in school. The teachers are considered to have the awareness to fulfill their work discipline process and desire to maintain the good name of themselves as teachers and also as ambassadors from their schools.
From the results of the regression analysis shows that work discipline variables positively influence teacher performance in line with previous research by Ivonne A. Sajangbati (2013)

The teachers feel real proof of the foundation's commitment in every agreement that has been given to them. Every year, the foundation gives appreciation for rewards to all teachers who excel in the internal and external arena. This makes the sense of ownership and pride of the school towards the teachers, so that in the end the performance of teachers is getting better and the foundation has teachers who are also fully committed to the school. This is consistent with previous research conducted by EdySujana (2012) which shows that organizational commitment or in this case the foundation is able to positively influence teacher performance.

The influence of the school environment on teacher performance was considered to be significantly positive. Every change that occurs in the school environment makes teachers more enthusiastic to carry out their responsibilities. Both physical and non-physical work environments have indications that affect teacher performance. Where the teacher is considered to have a happy feeling about every positive change in the physical environment of the school. Coupled with a nonphysical school environment that 
further strengthens feelings of pleasure and working conditions that have positive energy. Teachers are able to show their work well either consciously or not due to changes in the latest facilities and also the atmosphere of relationships between teachers that are built with solid family and cooperation. Based on this situation, it can be concluded that in the physical and non-physical work environment the teachers here are considered good, it means the teachers do not have problems between fellow teachers, they are considered capable of implementing good manners between fellow and superiors. The results of this study are in line with research conducted by Aurelia Potu (2013) which shows that school environment variables have a significant positive effect on teacher / employee performance.

\section{CONCLUSION}

The influence of work discipline on teacher performance shows that there is a positive relationship that influences one another. The rules of the school are considered not longwinded and have a fair value to be implemented. Both physical and nonphysical work environments have indications that affect teacher performance. Where the teacher is considered to have a happy feeling about every positive change in the physical environment of the school. Coupled with a non-physical school environment that further strengthens feelings of pleasure and working conditions that have positive energy.

Good teacher performance was found in Pelita Harapan Bangsa schools, which was firstly caused by an increase in the quality of school facilities that complemented the work assignments of teachers and also non-physical work environment factors that were able to create a sense of excitement and enthusiasm for teachers to carry out their duties enthusiastically. Researchers gave good results that the commitment of the foundation had a positive influence on the performance of the Pelita Harapan Bangsa Tegal teacher. There are several organizational commitments that must be evaluated in this school so that they can be categorized as good by measuring their indicators.

The work discipline of the teacher is also very important, especially the discipline that runs on the basis of the teacher's awareness from his deepest heart. This shows that school rules are not a burden and a barrier for teachers. All teachers carry out their duties with awareness even because of their pride in the school. The teacher fulfills all his duties with good obligations based on a sense of belonging and also integrity that is shown as learning for his students. This is considered very good for the school operational process. Discipline that applies to all levels is considered to have a good effect, because teachers will see for themselves that their leaders show commitment to the importance of work discipline in the school. 



\section{REFERENCES}

Aritonang, K. T. (2005). Kompensasi Kerja, Disiplin Kerja Guru dan Kinerja Guru SMP Kristen BPK Penabur Jakarta. Jurnal Pendidikan Penabur.

Cintia, E., \& Gilang, A. (2016). Pengaruh Lingkungan Kerja Fisik Dan Nonfisik Terhadap Kinerja Karyawan Pada Kppn Bandung I. Jurnal Sosioteknologi.https://doi.org/1 0.5614/sostek.itbj.2016.15.1.12 Fachreza., Said Musnadi., dan M. S. A. M. (2018). Pengaruh Motivasi Kerja, Lingkungan Kerja, dan Budaya Organisasi Terhadap Kinerja Karyawan dan Dampaknya Pada Kinerja Bank Aceh Syariah di Kota Banda Aceh. Jurnal Magister Manajemen.

Ingarianti, T. M. (2015). Pengembangan alat ukur komitmen organisasi. Jurnal RAP UNP.

Josephine, A., \& Harjanti, D. (2017). Pengaruh Lingkungan Kerja terhadap Kinerja Karyawan pada Bagian Produksi melalui Motivasi Kerja sebagai Variabel Intervening pada PT. Trio Corporate Plastic (Tricopla).Jurnal AGORA.

Kawet, L. (2016). Pengaruh Lingkungan Kerja, Disiplin Kerja, dan Loyalitas Kerja terhadap Kinerja Karyawan pada LPP RRI Manado. Jurnal Riset Ekonomi, Manajemen, Bisnis Dan Akuntansi.

Lestary, L., \& Harmon, H. (2018). Pengaruh Lingkungan Kerja
Terhadap Kinerja Karyawan. Jurnal Riset Bisnis Dan Investasi.

https://doi.org/10.35697/jrbi.v3 i2.937

Mananeke, L., Mandey, S., \& Katiandagho, C. (2014). Pengaruh Disiplin Kerja Kepemimpinan Dan Motivasi Terhadap Kinerja Pegawai Pada Pt. Pln (Persero) Wilayah Suluttenggo Area Manado. Jurnal Riset Ekonomi, Manajemen, Bisnis Dan Akuntansi.

Meutia, K. I., \& Husada, C. (2019).Pengaruh Budaya Organisasi Dan Komitmen Organisasi Terhadap Kinerja Karyawan. Jurnal Riset Manajemen Dan Bisnis (JRMB) Fakultas Ekonomi UNIAT.https://doi.org/10.3622 6/jrmb.v4i1.246

Prakoso, R. (2014). Pengaruh Lingkungan Kerja Terhadap Motivasi Kerja Dan Kinerja Karyawan (Studi Pada Karyawan PT. AXA Financial Indonesia Cabang Malang). Jurnal Administrasi Bisnis S1 Universitas Brawijaya.

Prayogi, M. A., Lesmana, M. T., \& Siregar, L. H. (2019). Pengaruh Kompetensi Dan Disiplin KerjaTerhadap Kinerja Pegawai. Prosiding FRIMA (Festival Riset Ilmiah Manajemen Dan Akuntansi).

Rep, A., Kojo, C., \& Pattynama, J. V. (2016). Pengaruh Motivasi Kerja, Disiplin Kerja, Dan Kepemimpinan Terhadap 
Prestasi Kerja Pegawai Di Badan Perpustakaan Provinsi Sulawesi Utara. Jurnal Riset Ekonomi, Manajemen, Bisnis Dan Akuntansi.

Rumondor, V. (2013). Motivasi, Disiplin Kerja, Dan Kepemimpinan Terhadap Produktivitas Kerja Pada Badan Kepegawaian Dan Diklat Daerah Minahasa Selatan. Jurnal EMBA: Jurnal Riset Ekonomi, Manajemen, Bisnis Dan Akuntansi.

Sarwono, J. (2007). Analisis Jalur untuk Riset Bisnis dengan SPSS. Jurnal JIBEKA.

Setyorina, Christina T., Magfiroh, S., \& Nur Farida, Y. (2012). Pengaruh komitmen organisasi, budaya organisasi, dan keterlibatan kerja terhadap kinerja karyawan baitul maal wattamwil (BMT). Media Riset Akuntansi.
Sidanti, H. (2015). Pengaruh Lingkungan Kerja, Disiplin Kerja Dan Motivasi Kerja Terhadap Kinerja Pegawai Negeri Sipil Di Secretariat DPRD Kabupaten Madiun. Jurnal JIBEKA.

Sudarwati, S. (2014). Pengaruh Motivasi, Disiplin Kerja Dan Kompetensi Terhadap Kinerja Pegawai Dinas Pendidikan Kabupaten Sragen. Jurnal Paradigma Universitas Islam Batik Surakarta.

Susanty, A., \& Baskoro, S. W. (2012).Pada Kinerja Karyawan (Studi Kasus Pada PT . PLN (Persero ) Apd Semarang ). Jati UNDIP.

Sutrisno, Fathoni, A., \&Minarsih, M. M. (2016).Pengaruh Motivasi Dan Disiplin Kerja Terhadap Kinerja Pegawai Di Kantor Satuan Polisi Pamong Praja Kota Semarang. Journal of Management. 